is that I have found such varying degrees of coalescence between the cartilaginous rays of the dorsal fins as may go far to bridge over the differences between the two orders of fins, while the close resemblance sometimes presented by paired fins to azygos fins (some of the ventrals being so nearly like certain dorsal and anal fins), is such that I think a conclusion in favour of their essential similarity of nature cannot be successfully contested.

As to the dorsal fin, I have found incipient coalescence between the rays, in Scyllian canicula, Ginglymostoma cirratum, and others, but in Notidanus cinereus I have found this process carried to such a degree, that there comes to be one continuous basal cartilage to the dorsal margin of which the cartilaginous rays are appended.

In Pristis and Pristiophorus I found a very interesting condition which I am not aware has been described. The rays in these genera repose upon solid cartilages which are absolutely continuous with the subjacent axial skeleton. I would suggest that the lateral pressure of the saw-like rostrum must be aided in these fishes by such a firm attachment of the dorsal fin cartilages to the vertebral column.

ST. GEORGE MIVART

(To be continued)

\section{A HUNTING WASP}

T

$\mathrm{HE}$ following interesting account of a chase between a wasp and a spider has been forwarded to us by Mr. Henry Cecil, who, it may be remembered, wrote to NATURE on the subject (vol. xvii. p. 38r) :-

The Piræus, Athens, June I9

DEAR SIR,-Your letter of April 5, and the two numbers of NATURE, reached this during my absence in Thessaly, which must be my apology for not having sooner replied to your letter.

Though more than thirty years have elapsed since the circumstance alluded to, I perfectly remember the curious chase I witnessed of a very large and powerful huntingspider by a species of wasp.

I was sitting one summer's afternoon at an open window (my bed-room) looking into a garden, when I was surprised to observe a large and rare species of spider run across the window-sill in a crouching attitude. It struck me the spider was evidently alarmed or it would not have so fearlessly approached me. It hastened to conceal itself under the projecting edge of the windowsill inside the room, and had hardly done so when a very fine large hunting-wasp buzzed in at the open window and flew about the room evidently in search of something. Finding notbing the wasp returned to the open window and settled on the window-sill, running backwards and forwards as a dog does when looking or searching for a lost scent. It soon alighted on the track of the poor spider, and in a moment it discovered its hiding-place, darted down on it, and no doubt inflicted a wound with its sting. The spider rushed off again and this time took refuge under the bed, trying to conceal itself under the framework or planks which supported the mattress. The same scene occurred here, the wasp never appeared to follow the spider by sight, but ran backwards and forward in large circles like a hound. The moment the trail of the spider was found the wasp followed all the turns it had made till it came on it again. The poor spider was chased from hiding-place to hiding-placeout of the bedroom across a passage and into the middle of another large room, where it finally succumbed to the repeated stings inflicted by the wasp. Rolling itself up into a ball the wasp then took possession of its prey, and after ascertaining it could make no resistance, tucked it up under its very long hind legs just as a hawk or eagle carry off their quarry, and was flying off to its nest, when I interposed and secured both for my collection.

Both insects were rare ones, and during the ten years I collected as a field naturalist in Greece, I don't remem- ber ever seeing more than three or four specimens of either that species of wasp or spider.

The wasp was a hunting one (a female) about an inch and-a-half long, a very finely formed insect, which for gracefulness of form and beauty of colouring is entitled to be placed at the head of its species. The legs of this kind of wasp are very long and of a dark chocolate brown. It runs very quickly. The wings are a lightbrown with dark-brown tips and long and powerful, and the body beautifully mottled with pale yellow and brown. It has very long fine antennæ. It is not an English species, but probably exists in Spain, the south of France, and Italy.

The spider, too, was a rare one. One of the largest Greek hunting-spiders, nearly as large in the spread of its legs as the flesh-coloured tarantula though without his powerful crab-like pincers. The one I allude to must have covered at least three inches in circumference when its legs were fully extended. It was of a dull mottled brown colour on the upper surface of the body. Very difficult to distinguish from the ground. The lower part of its body was, however, brilliantly coloured, the long legs, or arms, being marked underneath with velvet-like looking black and white rings. The head, thorax, and abdomen were of a velvety black, the lower portion of the latter surrounded with a bright orange ring.

There is only one error in the account given by you in NATURE, that is, that you were under the impression I told you, that kind of spider was the common prey of that species of wasp. You must have misunderstood me.

I. I do not think that particular kind of spider is sufficiently common for this to be the case.

2. I never saw a similar conflict of the kind before or after, which as it was in a room, and not in the grass, where I presume such encounters usually take place, I observed under exceptionally favourable circumstances.

I am certain the spider left no web or thread behind it. I cannot be sure, however, that, as it had evidently been attacked by the wasp before entering my room, a small quantity of liquid may not have exuded from its wounds, which may have helped the wasp in tracking it. I have no doubt myself that insects have the sense of smell, and probably much more developed than our own. No one, as you remark, who has sugared for moths, or seen the large sphingidæ hovering over the strongest scented flower at night, or employed a caged female moth as a lure to her male admirers, can, I think, doubt this. If so, let them put a saucerful of honey in a corner of a room opening into a garden, throw open the window, and see how soon the bees, wasps, \&c., will be attracted to the honey.

There is a tradition in the east that one of the tests by which the Queen of Sheba tried to prove the wisdom of Solomon, was placing on a table before him two bouquets, one of artificial, and the other of natural flowers, and requiring that he should say which were the real and which the artificial, without moving from his throne. Solomon ordered the windows to be thrown open, and in flew the bees, \&c., which went at once to the real flowers.

Whether the senses of insects, birds, and what we call the lower creation, are similar to ours in every respect, it is very difficult to say. No doubt a dog, if he could speak, would say a man had not the sense of smell, and would prove that his nose was worse than useless to him. An eagle or hawk would say that men and moles, \&c., have only the rudiments of eyes, and so on.

Man, with five very imperfectly developed senses (who can say that there are not twenty senses), is the only animal that is dogmatical, and denies all he cannot understand. The oracle of Delphi said "Socrates was the wisest man in Greece, because he was the only man who knew he knew nothing." Yours faithfully,

To Henry Cecil, Esq., Bournemouth.
C. L. W. MERLIN 